\title{
Competitiveness of high-tech exports in the EU countries
}

\author{
Mirosława Braja \\ Department of Economics and Finance, University of Information \\ Technology and Management in Rzeszów, \\ Poland \\ mbraja@,wsiz.rzeszow.pl \\ Agata Gemzik-Salwach \\ Department of Economics and Finance, University of Information \\ Technology and Management in Rzeszów, \\ Poland \\ agemaik@wsiz.rzeszow.pl
}

Abstract. The global economy is changing rapidly. In recent years we have witnessed radical changes in global exports, as well as in manufacturing sectors. The increasing role of innovative and disruptive technologies was one of the critical factors that stimulated these processes. Nowadays, knowledge-intensive and innovation-absorbing industries are perceived as primary drivers of economic growth and economy's competitiveness. On the other hand, developed and competitive economies can create a favorable environment for further adoption of the newest technologies and serve as reservoirs for the most promising technologies. Globalisation and internationalisation, as well as evolution of global trade relations, affect both businesses and economies. Also, observed technology spillovers and trade shifts have led to reformulation and redefinition of competitive advantages. This paper aims at evaluating export performance and competitiveness in high-tech sector across the EU. The authors have conducted this study using constant market shares analysis (CMS), a well-known method of export decomposition.

Keywords: competitiveness, high technologies, constant market shares, export decomposition, European Union.

JEL Classification: O14, O30, D89; F10. 


\section{INTRODUCTION}

This paper provides some insights into the development of competitiveness and the structure of high-tech export in particular EU member states.

Knowledge incorporated in new technologies, highly processed products, highly qualified labour resources that create and use these technologies, as well as products and services, determines the innovativeness of economy and its international competitiveness. Being competitive in trading advanced, technology-based goods is the most demanded way of competing with other entities. Under the criteria adopted by the OECD high technology industries include (Hatzichronoglou, 1996; Galindo-Rueda \& Vender, 2016; Bilan et al., 2017):

- production of basic pharmaceutical substances and medications, as well as other pharmaceutical products,

- production of computers, electronics and optical products,

- production of aircrafts, spaceships and similar machines.

In the recent years, different ground-breaking technologies appeared in the pharmaceutical and medical industry (i.e. cell and gene therapies, liquid biopsies), in the electronic (i.e. Internet of Things), in the IT sector (i.e. blockchain). The growing role of new technologies is changing our daily lives, and reshaping the production processes in the global manufacturing sectors (Montobbio \& Rampa, 2005; Olczyk \& Kordalska, 2019).

In the macro scale, it leads to changes in the economic relations and causes changes in global exports. In 2018, high technology products accounted for $17.87 \%$ of global export of manufactured goods (World Bank, 2020). Furthermore, the run for global markets of high-tech products is no longer limited to the competition between the EU, the US and Japan (Pasierbiak, 2013).

One of the major changes is observed in Asian countries, previously perceived as developing ones concentrated on primary production. These countries became important players in various industries. In the recent years, China became the biggest global economy in terms of purchase parity (McKinsey, 2019). The country reached a new stage of global expansion shifting from being a cheap subcontractor to the position of a worldwide leader in technology-related industries and also as a capital owner. Furthermore, the position of other Asian countries (i.e. Taiwan, Singapore, South Korea) in the global high technology trade is improving rapidly. These shifts change the patterns of global trade flows (Widodo, 2010).

Nevertheless, European Union overall remains one of the key global manufacturers of hightechnology products. However, the contribution to this global leadership differs among various member states. As Skórska (2016) noticed, the competitiveness of high-tech industries diversifies the EU. This is in particular caused by the fact that business environment, knowledge adoption, R\&D activities and economic conditions in the European Union countries' vary, despite common policy assumptions, similar instruments and common market (Domańska \& Zajkowski, 2018). Therefore, the following question arises: "What is the EU's member states potential in the global technology trade?".

This paper aims at examining changes in the export of high-tech goods in the EU countries. To achieve this goal, the authors analysed the Eurostat data for the period of 2008-2017. The key method used is constant market shares analysis (CMSA), which is one of the most widely employed descriptive tools for measuring export competitiveness of a country relative to other countries or regions in terms of trade in goods and services (Nuddin et al., 2018).

This paper is divided into five sections and is organised as follows. Chapter 2 aims at examining the theoretical aspects of this study and presenting the existing studies related to competitiveness of high-tech goods trade. High-tech goods play an essential role in shaping the competitiveness of developed economies. Chapter 3 shows the main methods applied in this particular study and is mainly focused on 
the characteristics of constant market shares analysis. In the 4th chapter, the authors present the obtained results. Also, this chapter aims at discussing the obtained results. The paper ends with the summary and conclusions formulated in the final chapter.

\section{THEORETICAL BACKGROUND}

\subsection{Research on export competitiveness}

Several studies were examining the relationship between trade performance and economic growth. Among various measures of the countries' performance, trade results of a country can be a good indicator of development. However, there is a long list of critical factors that shape the competitiveness of the country, i.e. governance, the quality of institutions, levels of education and health, and law and order. In general, Kovacić argues that high-quality export is crucial for financing the welfare state (Kovačič, 2005).

On the other hand, there is a link between a particular stage of competitive development and the particular pattern of export competitiveness (Ozawa 1992). Grossman and Helpman (2015) argue that international operations allow innovators to exploit their new ideas on a larger stage. The success in international markets, which is measured by export shares, is an indicator of integration in global trade. The new technologies currently drive much of this success. Knowledge-intensive and innovationabsorbing industries are perceived as primary drivers of economic growth and economy's competitiveness (Aiginger, 1998; Cortright \& Meier, 2001; Lu \& Yu, 2010; Simonen et al., 2013; Skórska, 2016).

Research prove that developed economies can create a favorable environment for further adoption of the newest technologies and serve as reservoirs for the most promising technologies (Ozawa, 1992; Gökmen and Turen, 2013; Skórska, 2016). As such, innovation-driven economies are perceived as the highest level of economic development (Porter, 1990; Ozawa, 1992). Also, their high-tech companies' growth is mainly based on the development of information and technology. Moreover, emphasising these products in the field of exports will also cause countries to have a comparative advantage in the foreign market (Yildimiz et al., 2017). Equivalently, the technology-intensive exports cause positive productivity differential to the domestic sector. However, export stimulates growth mainly through increased productivity and not via external effects, like knowledge or technology spillovers. (Crespo-Guaresma \& Worz, 2003).

International competitiveness in high-technology goods is particularly essential for small and open economies, as it not only gives them the opportunity to improve their place in the international division of labour, and thus achieve faster economic growth, but it can also create a sufficient buffer against unpredictable external price shocks of labour and capital-intensive goods (Falkowski 2018; Buturac et al., 2019). Despite this fact, the trade theories are mainly focused on the effects of technology disparities (Grossman \& Helpman, 1995) and not in their causes (Wolfmayr-Schnitzer, 1998).

\subsection{The use of the CMS model to probe export fluctuations}

One of the techniques adopted for analysis of trading patterns and trends is Constant market shares (CMS) analysis. Initially developed by Creamer as a method for the regional studies, it was adopted to the export analysis by Tyszynski (1951). Despite some limitations and weaknesses of the CMS (Houston, 1967; Richardson, 1971; Bowen \& Pelzman, 1984; Bonano, 2014), it is a widespread technique applied for export growth analysis (Ahmadi-Esfahani, 2006). Also, Merkies and van der Meer (1988) noticed that CMS is not relevant to the analysis of the long term export performance and suggested that this method should be applied mainly to the midterm assessments. 
The CMS analysis is based on the assumption that a country's share in world markets should remain constant over time (Skriner, 2009). Tyszynski referred to the difference between the hypothetical market share and the initial share as a change in the market share caused by structural changes in world trade (i.e. Tyszynski, 1957; Fagerberg \& Sollie, 1987; Widodo, 2010).

In the CMS analysis, export change of a particular industry, sector or an economy as a whole depends on product composition, the geographical distribution of the exports, and the level of international competitiveness. (Buturan et al., 2019). However, the CMS model does not provide precise information on to what extent the particular single factors affect the export performance due to a large number of factors which should be taken into account as a whole. On the contrary, it explains the reason for a fluctuation in the export from the perspective of aggregates defined within the CMS framework (Wang et al., 2017).

It is also worth mentioning that, even if a country maintains its share of every product in every market, it still can have a decrease in its aggregate market share if it exports to markets that grow more slowly than the world's average (Buturan et al., 2019). Changes in exports of the particular sector or economy are assigned to the market structure or the competitive forces (Richardson, 1971).

\section{RESEARCH OBJECTIVE, METHODOLOGY AND DATA}

This study attempts to assess the impact of the competitiveness effect on the export growth in the EU member states. The study focuses on the high-tech sectors, according to the definition developed by OECD. The study covers 3 groups business activity at Nace Rev 2 3-digit level of aggregation, namely:

- Manufacture of basic pharmaceutical products and pharmaceutical preparations (group 21);

- Manufacture of computer, electronic and optical products (group 26);

- Manufacture of air and spacecraft and related machinery (group 30.3).

Authors' research was based on the Eurostat data and covered the period 2008-2017. Therefore, if not stressed otherwise, the UK was included in the study as the EU member state.

The research process was organized in 2 stages. First, the authors examined the production of hightech goods in the EU countries, as well as value of countries' export in the high tech manufactured goods. Here, we examined the share of high-tech products in exports, which can be used as a proxy for the technological intensity of local export (Srholec, 2007). Second, the authors applied the constant market shares analysis to examine the export changes in the particular high-tech industries.

The period of CMS analysis was divided into three subperiods: 2008-2011, 2012-2014 and 2015-2017. Such an approach makes the analysis more plausible and eliminates the impact of the business cycle on the obtained results (Fogarasi, 2008).

The first subperiod 2008-2011 was defined as the baseline period. This move let Authors eliminate the impact of changes in demand. Moreover, it allowed us to mitigate the impact of the economic crisis on economic activities.

The analysis of the export performance using the CMS begins with calculating the share of the EU member states in the EU trade in high-tech goods (see, i.e. Ahmadi-Esfahani, 2006), expressed as:

$$
S=\frac{x}{X}
$$

where:

$\mathrm{S}-\%$ share in the high-tech exports in the EU;

$\mathrm{x}$ and $\mathrm{X}$ - exports in the targeted country and in the relevant group of countries. 
The main estimation of the CMS model can be formulated as follows:

$$
x_{1}-x_{0}=r x_{0}+\sum_{i}\left(r_{i}-r\right) x_{i 0}+\sum_{i} \sum_{j}\left(r_{i j}-r_{i}\right) x_{i j 0}+\sum_{i} \sum_{j}\left(x_{i j 1}-x_{i j 0}-r_{i j} x_{i j 0}\right)
$$

where:

$r$ is the world trade growth rate,

$\mathrm{i}-$ is the relevant commodity,

$j$ - is the examined country,

$\mathrm{x}-$ is the export of the examined country,

is the basic period,

1- means the relevant analysed period.

The export growth is decomposed into four parts: the world term, the market term, the commodity term, and the competitiveness term (see i.e. Merkies \& van der Meer, 1988). This relationship can be written as follows (Milana 1988; Skriner, 2009):

$$
\mathrm{TE}=\mathrm{CE}+\mathrm{PE}+\mathrm{GE}+\mathrm{RE}
$$

where:

$\mathrm{CE}$ - is a competitive effect,

$\mathrm{PE}$ - is a product effect,

$\mathrm{GE}$ - is a geographical effect,

$\mathrm{RE}$ - is a residual effect.

The total effect (TE) can be defined as follows:

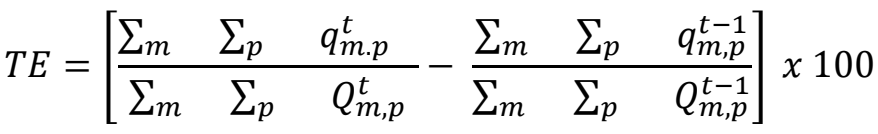

The CE effect can be defined as:

$$
C E=\sum_{m} \sum_{p} 0,5 *\left[\left(\frac{q_{m, p}^{t}}{Q_{m, p}^{t}}-\frac{q_{m, p}^{t-1}}{Q_{m, p}^{t-1}}\right)\right] *\left[\frac{Q_{m, p}^{t-1}}{\sum_{m} \sum_{p} Q_{m, p}^{t-1}}+\frac{Q_{m, p}^{t}}{\sum_{m} \sum_{p} \quad Q_{m, p}^{t}}\right] * 100
$$

The PE effect can be defined as:

$$
P E=\sum_{m} \sum_{p} 0,5 *\left[\left(\frac{q_{m, p}^{t-1}}{Q_{m, p}^{t-1}}+\frac{q_{m, p}^{t}}{Q_{m, p}^{t}}\right)\right] *\left[\frac{\sum_{m} Q_{m, p}^{t-1}}{\sum_{m} \sum_{p} Q_{m, p}^{t}}-\frac{\sum_{m} Q_{m, p}^{t}}{\sum_{m} \sum_{p} Q_{m, p}^{t-1}}\right] * 100
$$

The GE effect can be defined as:

$$
G E=\sum_{m} \sum_{p} 0,5 *\left[\left(\frac{q_{m, p}^{t-1}}{Q_{m, p}^{t-1}}+\frac{q_{m, p}^{t}}{Q_{m, p}^{t}}\right)\right] *\left[\frac{\sum_{m} Q_{m, p}^{t}}{\sum_{m} \sum_{p} Q_{m, p}^{t}}-\frac{\sum_{m} Q_{m, p}^{t-1}}{\sum_{m} \sum_{p} Q_{m, p}^{t-1}}\right] * 100
$$

The residual effect (RE) can be calculated as:

$$
\mathrm{RE}=\mathrm{TE}-(\mathrm{CE}+\mathrm{PE}+\mathrm{GE})
$$

where: 
qt - aggregate exports of an industry,

qt p exports of the $\mathrm{p}$-th commodity of an industry,

Qt p world exports of the p-th commodity,

$\mathrm{M}$ - market index,

$\mathrm{p}$ - product index,

$\mathrm{t}$ - time.

The formal economic interpretation of the CMS analysis components is presented below.

The total effect (TE) measures the change in the total export share of a country over the reviewed period (Dyadkova \& Momchilow, 2014). Positive value suggests that the exports of a certain industry expanded faster compared to the rest of the world, while a negative value indicates the opposite (Milana, 1988; Buturan et al., 2019).

The product effect (PE) estimates the influence of the product specialisation of a country's exports. If a country produces and exports products with a growing foreign demand, then the product composition effect will have a positive pattern. Product specialisation gains are envisaged in this equation (Milana, 1988; Skriner, 2009; Buturan et al., 2019).

The geographical effect (GE) is also known as the market distribution effect. It measures the effect generated by the geographical breakdown of a country's exports. A positive result means that a country's foreign trade is directed to markets, where the demand is strongly growing. A negative value shows that the exports of the focus country are directed to markets in which demand is growing slower than in the rest of the world (Milana, 1988; Skriner, 2009; Buturan et al., 2019).

The residual effect $(\mathrm{RE})$ considers all the remaining aspects that were not incorporated into the model. In many previous studies the scope of analysis was usually limited to the competitiveness term. The competitiveness effect (CE) is the capacity of a country to increase its market share due to competitiveness factors only, independently of structural developments in the market or in the product trade pattern. If a country exports certain traditional products for which international demand is growing slowly compared to other products, then its total export market share of world trade will decline even if this country succeeds in maintaining its market share in these traditional products (Milana, 1988; Skriner, 2009; Buturan et al., 2019).

\section{RESULTS AND DISCUSSION}

Share of high-tech products in the EU export in 2018 was estimated at 16,2\% (decrease from 17,2\% in 2009). This change was actually in line with the global changes: in 2009, approx.. 21,17\% of global export was assigned to the high-tech products, while in 2018 high-tech share in global export was estimated at $17,87 \%$. In the US, export of high-tech manufactured goods accounted for $25,01 \%$ of country export and in the next years it was going down, reaching $18,9 \%$ in 2018, the lowest level in the analysed 10-year period (see table 1).

On the contrary, the role of high-tech export in Asian countries was growing. In China, export of high-tech products accounted for 29,7-32,15\% of country export value. Share of the high-products in South Korean export exceeded 36\% in 2018. Also it is interesting how Vietnam changed its' export patterns: A country where high tech goods accounted for only 13\% of export in 2009 made a huge shift and in 2017 high-tech export created over $41 \%$ of country export.

This may be related to i.e. rising labour costs in different countries across the globe. An in-depth analysis of this phenomenon exceeds the scope of this study, but will be further examined in the future. 
Table 1

Share of high-tech products in the EU vs. main competitors

\begin{tabular}{|l|c|c|c|c|c|c|c|c|c|c|}
\hline Country/group of countries & 2009 & 2010 & 2011 & 2012 & 2013 & 2014 & 2015 & 2016 & 2017 & 2018 \\
\hline European Union & 17,36 & 17,58 & 16,94 & 17,45 & 17,49 & 17,40 & 18,01 & 18,21 & 16,69 & 16,27 \\
\hline World & 21,17 & 20,56 & 18,72 & 19,03 & 19,06 & 19,09 & 20,04 & 20,04 & 19,65 & 17,87 \\
\hline Switzerland & 26,79 & 25,91 & 25,38 & 26,38 & 27,06 & 26,97 & 27,35 & 27,58 & 14,08 & 13,37 \\
\hline China & 31,95 & 32,15 & 30,50 & 30,86 & 31,58 & 29,70 & 30,43 & 30,25 & 30,89 & \\
\hline High income & 21,38 & 20,78 & 18,97 & 19,00 & 18,75 & 18,80 & 19,71 & 19,87 & 18,99 & 18,49 \\
\hline Japan & 20,59 & 19,16 & 18,43 & 18,30 & 17,82 & 17,79 & 18,07 & 17,34 & 17,56 & 17,27 \\
\hline Korea, Rep. & 32,03 & 32,04 & 28,14 & 28,20 & 29,80 & 30,03 & 31,21 & 30,52 & 32,52 & 36,35 \\
\hline OECD members & 19,55 & 19,25 & 18,32 & 18,65 & 18,78 & 18,75 & 19,41 & 19,64 & 17,83 & 17,63 \\
\hline United States & 25,01 & 23,12 & 21,07 & 20,66 & 20,65 & 21,00 & 21,95 & 23,01 & 19,69 & 18,90 \\
\hline Vietnam & 10,45 & 13,00 & 18,60 & 26,89 & 33,22 & 31,74 & & 37,76 & 41,41 & \\
\hline
\end{tabular}

Source: own elaboration based on the World Bank data.

In 2016, 47682 enterprises in the EU were producing the high-tech manufacturing goods, out of which 7528 were located in the UK, 7716 in Germany and 5530 in Italy. Total value of high-tech manufacturing production in $22 \mathrm{EU}$ member states (unavailable data on production in Estonia, Ireland, Cyprus, Luxembourg, Slovenia and Sweden) was estimated at 668104 million EUR, with significant contribution of companies located in Germany (156940 million EUR), France (167 788 million EUR) and the UK (74 864 million EUR).

In Europe, the countries that are leading in the statistics in the development of new technologies are: United Kingdom, Germany and France. This is because in Europe there is widespread reluctance to finance risky ventures, and the high technology sector is associated with high uncertainty and a high level of investment risk (Ratajczak-Mrozek, 2011). The development of high technology industry in Europe is different from the other leading countries in this regard. Traditional, though constantly modernized, automotive, chemical and electrotechnical industries dominate in Europe. This interesting difference prompted the authors to analyze the high technology sector in the European Union.

In the analyzed period, 2008-2017 share of high-tech manufactured goods in the EU grew to reach $17,8 \%$ share in the total EU export. It means that the share of the high-tech products grew at a compound annual growth rate (CAGR) at 0,9 p.p. between 2007-2017. It should be stressed that the share of hightech export in the CEE was growing faster than in the EU-15. The fastest growth rate was reported by Poland (9,8\%), Latvia (7,9\%), Slovakia $(7,0 \%)$ and Romania $(7,7 \%)$.

During this period, the share of high-tech export in the total export rose in twenty-one EU member states. In those countries the share of high-tech goods in the total foreign trade was growing at a positive CAGR, varying between $0,2 \%$ in Greece and $9,8 \%$ in Poland. 
Table 2

Share of high-tech products in the EU member states

\begin{tabular}{|c|c|c|c|c|c|c|c|c|c|c|c|}
\hline Country Name & 2008 & 2009 & 2010 & 2011 & 2012 & 2013 & 2014 & 2015 & 2016 & 2017 & CAGR \\
\hline Austria & 12,68 & 13,45 & 13,71 & 13,26 & 14,58 & 15,41 & 15,53 & 15,08 & 14,51 & 12,87 & $0,9 \%$ \\
\hline Belgium & 8,95 & 11,36 & 11,17 & 10,55 & 11,86 & 12,03 & 13,36 & 13,65 & 13,05 & 10,70 & $3,7 \%$ \\
\hline Bulgaria & 7,02 & 8,70 & 8,43 & 7,83 & 8,05 & 8,29 & 7,36 & 8,19 & 8,87 & 9,53 & $4,0 \%$ \\
\hline Cyprus & 32,02 & 32,53 & 38,20 & 30,31 & 16,59 & 13,08 & 14,59 & 13,14 & 13,43 & 14,05 & $1,2 \%$ \\
\hline Czech Republic & 15,77 & 17,43 & 17,87 & 18,71 & 18,59 & 17,35 & 17,40 & 17,79 & 16,99 & 17,90 & $-1,8 \%$ \\
\hline Germany & 15,13 & 16,88 & 17,01 & 16,45 & 17,36 & 17,39 & 17,28 & 17,89 & 18,06 & 15,90 & $1,4 \%$ \\
\hline Denmark & 16,90 & 18,92 & 15,48 & 15,29 & 15,84 & 15,85 & 15,72 & 17,19 & 16,68 & 13,88 & $4,0 \%$ \\
\hline Spain & 5,74 & 6,70 & 6,78 & 6,82 & 7,36 & 8,08 & 7,43 & 7,58 & 7,45 & 7,74 & $2,7 \%$ \\
\hline Estonia & 10,77 & 10,31 & 15,67 & 22,16 & 20,45 & 20,54 & 23,33 & 22,44 & 22,02 & 17,56 & $0,2 \%$ \\
\hline Finland & 21,55 & 18,09 & 13,18 & 11,11 & 10,52 & 9,09 & 10,13 & 10,21 & 10,06 & 9,56 & $2,8 \%$ \\
\hline France & 21,74 & 24,38 & 26,59 & 25,32 & 26,85 & 27,28 & 27,61 & 28,36 & 28,08 & 26,09 & $1,9 \%$ \\
\hline \begin{tabular}{|l|} 
United Kingdom \\
\end{tabular} & 20,84 & 20,80 & 23,55 & 23,58 & 23,80 & 23,88 & 22,47 & 22,67 & 23,98 & 23,03 & $3,2 \%$ \\
\hline Greece & 10,98 & 12,15 & 11,51 & 11,15 & 10,06 & 8,38 & 11,40 & 12,81 & 13,62 & 11,99 & $2,2 \%$ \\
\hline Croatia & 9,53 & 11,39 & 10,21 & 8,72 & 11,89 & 12,63 & 10,55 & 10,79 & 14,70 & 8,80 & $-3,2 \%$ \\
\hline Hungary & 24,94 & 26,71 & 25,90 & 25,15 & 21,20 & 19,36 & 16,68 & & 17,47 & 17,30 & $7,9 \%$ \\
\hline Ireland & 28,72 & 26,43 & 22,82 & 24,80 & 25,48 & 24,84 & 24,78 & 28,20 & 32,72 & 29,03 & $0,9 \%$ \\
\hline Italy & 7,30 & 8,40 & 8,15 & 8,07 & 7,67 & 7,91 & 7,82 & 8,29 & 8,37 & 7,91 & $-13,2 \%$ \\
\hline Lithuania & 11,83 & 10,61 & 11,26 & 10,64 & 11,06 & 11,06 & 11,16 & 12,81 & 12,72 & 12,57 & $-2,6 \%$ \\
\hline Luxembourg & 8,01 & 10,32 & 8,77 & 9,05 & 8,68 & 6,85 & 5,97 & 7,11 & 7,97 & 7,14 & $-4,6 \%$ \\
\hline Latvia & 7,33 & 8,63 & 8,31 & 9,32 & 11,25 & 15,22 & 17,69 & 18,83 & 17,14 & 17,50 & $1,5 \%$ \\
\hline Malta & 50,45 & 48,04 & 47,18 & 47,55 & 46,13 & 38,77 & 34,78 & 30,45 & 21,99 & & $2,6 \%$ \\
\hline Poland & 5,23 & 7,09 & 7,72 & 6,62 & 7,89 & 8,85 & 10,25 & 11,02 & 11,04 & 10,89 & $9,8 \%$ \\
\hline Portugal & 8,21 & 4,79 & 4,06 & 4,11 & 4,48 & 4,68 & 4,86 & 5,06 & 5,78 & 5,96 & $-3,7 \%$ \\
\hline Romania & 6,92 & 10,38 & 12,51 & 11,63 & 8,13 & 7,36 & 8,39 & 9,41 & 10,39 & 9,82 & $7,7 \%$ \\
\hline Slovak Republic & 5,08 & 6,36 & 7,12 & 7,38 & 9,58 & 11,02 & 11,14 & 11,15 & 10,74 & 11,80 & $1,8 \%$ \\
\hline Slovenia & 6,45 & 6,82 & 6,06 & 6,21 & 6,65 & 6,73 & 6,41 & 7,00 & 7,14 & 6,50 & $7,0 \%$ \\
\hline Sweden & 17,32 & 18,85 & 19,66 & 18,76 & 18,00 & 18,00 & 17,98 & 18,13 & 18,28 & 15,38 & $-8,5 \%$ \\
\hline Central Europe and the Baltics & 11,31 & 12,91 & 13,21 & 12,92 & 12,62 & 12,47 & 12,64 & 12,56 & 13,20 & 13,03 & $-1,0 \%$ \\
\hline Euro area & 15,51 & 17,06 & 17,04 & 16,30 & 17,00 & 17,14 & 17,23 & 17,85 & 18,01 & 16,38 & $0,7 \%$ \\
\hline
\end{tabular}

Source: own elaboration based on the World Bank and Eurostat data.

Seven EU member states registered a negative CAGR, which meant that the share of the high-tech manufactured goods in the overall trade of a given country decreased (see Tab. 1). Perhaps the reason for this is the lack of suitably qualified employees. Research published by the European Commission (2003) indicates the lack of qualified staff as one of the main barriers to the development of European small and medium enterprises in the advanced technologies sector. The high qualifications of employees employed in the high technology sector are particularly important in the context of fact. We are dealing here with a short product life cycle and high intensity of research and development work required. 
Table 3

Structure of the EU trade in high-tech manufactured goods in the baseline period 2008-2011 by country

\begin{tabular}{|c|c|c|c|c|}
\hline & Total high-tech & Aviation & Electro & Pharma \\
\hline Austria & $2,92 \%$ & $5,17 \%$ & $54,19 \%$ & $40,64 \%$ \\
\hline Belgium & $7,83 \%$ & $2,00 \%$ & $43,10 \%$ & $54,91 \%$ \\
\hline Bulgaria & $0,42 \%$ & $2,76 \%$ & $56,18 \%$ & $41,06 \%$ \\
\hline Croatia & $0,22 \%$ & $8,23 \%$ & $44,46 \%$ & $47,31 \%$ \\
\hline Cyprus & $0,03 \%$ & $3,35 \%$ & $35,19 \%$ & $61,46 \%$ \\
\hline Czech Republic & $2,61 \%$ & $3,23 \%$ & $90,29 \%$ & $6,48 \%$ \\
\hline Denmark & $1,88 \%$ & $0,87 \%$ & $75,00 \%$ & $24,13 \%$ \\
\hline Estonia & $0,25 \%$ & $0,72 \%$ & $94,99 \%$ & $4,29 \%$ \\
\hline Finland & $1,31 \%$ & $2,87 \%$ & $84,19 \%$ & $12,95 \%$ \\
\hline France & $10,01 \%$ & $26,55 \%$ & $55,54 \%$ & $17,91 \%$ \\
\hline Germany & $24,21 \%$ & $8,00 \%$ & $76,32 \%$ & $15,69 \%$ \\
\hline Greece & $0,57 \%$ & $12,84 \%$ & $54,96 \%$ & $32,20 \%$ \\
\hline Hungary & $1,82 \%$ & $0,18 \%$ & $88,31 \%$ & $11,51 \%$ \\
\hline Ireland & $2,21 \%$ & $1,02 \%$ & $53,45 \%$ & $45,53 \%$ \\
\hline Italy & $8,65 \%$ & $7,88 \%$ & $66,23 \%$ & $25,89 \%$ \\
\hline Latvia & $0,21 \%$ & $2,57 \%$ & $61,98 \%$ & $35,44 \%$ \\
\hline Lithuania & $0,44 \%$ & $4,51 \%$ & $71,14 \%$ & $24,35 \%$ \\
\hline Luxembourg & $0,37 \%$ & $1,38 \%$ & $98,19 \%$ & $0,42 \%$ \\
\hline Malta & $0,07 \%$ & $2,82 \%$ & $79,11 \%$ & $18,07 \%$ \\
\hline Poland & $11,04 \%$ & $5,41 \%$ & $83,09 \%$ & $11,50 \%$ \\
\hline Portugal & $3,09 \%$ & $2,21 \%$ & $89,56 \%$ & $8,23 \%$ \\
\hline Romania & $0,97 \%$ & $2,98 \%$ & $83,56 \%$ & $13,46 \%$ \\
\hline Slovakia & $0,97 \%$ & $0,60 \%$ & $96,07 \%$ & $3,33 \%$ \\
\hline Slovenia & $1,30 \%$ & $2,08 \%$ & $34,66 \%$ & $63,26 \%$ \\
\hline Spain & $0,56 \%$ & $10,57 \%$ & $57,40 \%$ & $32,03 \%$ \\
\hline Sweden & $4,99 \%$ & $3,49 \%$ & $64,54 \%$ & $31,97 \%$ \\
\hline The Netherlands & $2,99 \%$ & $0,46 \%$ & $97,03 \%$ & $2,51 \%$ \\
\hline The UK & $8,07 \%$ & $15,11 \%$ & $64,84 \%$ & $20,05 \%$ \\
\hline
\end{tabular}

Source: own calculation based on Eurostat data

On the other hand, Germany, Poland and France remained the most important high-tech exporters across the EU, with the share of $24,21 \%, 11,04 \%$ and 10,01\% respectively in the baseline period (see Tab. 3).

It should be also noted that the share of aviation industry, electronics and pharmaceutical products in the countries' export differs among the member states. The detailed analysis was presented in the Table 3.

Also, the decomposition of the export growth brought some interesting results. The results obtained varied between two subperiods: 2012-2014 and 2015-2017 and were presented in Table 4. 
Table 4

Composition of the CMS model for the high-tech manufactured goods

\begin{tabular}{|c|c|c|c|c|c|c|c|c|c|c|}
\hline & \multicolumn{5}{|c|}{ 2012-2014 } & \multicolumn{5}{|c|}{ 2015-2017 } \\
\hline & TE & $\mathrm{CE}$ & $\mathrm{PE}$ & GE & $\mathrm{RE}$ & TE & $\mathrm{CE}$ & PE & GE & RE \\
\hline Austria & 0,43 & 1,24 & $-0,61$ & 2,71 & $-2,91$ & $-0,10$ & 0,64 & $-3,75$ & 3,24 & $-0,23$ \\
\hline Belgium & $-1,16$ & 1,51 & $-2,63$ & 13,15 & $-13,19$ & $-0,27$ & 2,22 & $-5,21$ & 11,28 & $-8,56$ \\
\hline Bulgaria & 0,04 & 0,09 & $-0,04$ & 0,18 & $-0,19$ & 0,01 & 0,06 & $-3,16$ & 0,23 & 2,89 \\
\hline Croatia & 0,01 & 0,04 & $-0,03$ & 0,13 & $-0,14$ & 0,05 & 0,10 & $-2,50$ & 0,13 & 2,32 \\
\hline Cyprus & 0,01 & 0,04 & $-0,02$ & 0,07 & $-0,08$ & 0,00 & 0,02 & $-1,96$ & 0,09 & 1,85 \\
\hline $\begin{array}{l}\text { Czech } \\
\text { Republic }\end{array}$ & 0,03 & 0,49 & $-0,58$ & 2,85 & $-2,73$ & 0,04 & 0,46 & $-5,83$ & 3,09 & 2,32 \\
\hline Denmark & $-0,22$ & 0,31 & $-0,67$ & 3,30 & $-3,17$ & $-0,11$ & 0,37 & $-5,00$ & 3,22 & 1,30 \\
\hline Estonia & 0,10 & 0,12 & $-0,04$ & 0,13 & $-0,11$ & $-0,04$ & $-0,02$ & $-5,31$ & 0,25 & 5,04 \\
\hline Finland & $-0,58$ & $-0,43$ & $-0,19$ & 1,24 & $-1,21$ & $-0,08$ & 0,06 & $-4,80$ & 0,66 & 4,00 \\
\hline France & $-0,14$ & 14,01 & $-6,12$ & 36,51 & $-44,54$ & $-1,53$ & 12,25 & $-8,47$ & 35,01 & $-40,32$ \\
\hline Germany & $-0,47$ & 14,74 & $-11,12$ & 57,61 & $-61,70$ & 0,95 & 15,56 & $-18,07$ & 59,92 & $-56,46$ \\
\hline Greece & $-0,02$ & 0,11 & $-0,11$ & 0,64 & $-0,65$ & 0,06 & 0,15 & $-3,18$ & 0,54 & 2,55 \\
\hline Hungary & $-0,81$ & $-0,39$ & $-0,59$ & 3,21 & $-3,04$ & $-0,36$ & $-0,04$ & $-5,56$ & 2,65 & 2,59 \\
\hline Ireland & $-1,60$ & 0,76 & $-2,08$ & 10,55 & $-10,82$ & 1,90 & 4,94 & $-5,44$ & 8,93 & $-6,52$ \\
\hline Italy & 0,28 & 2,98 & $-2,00$ & 9,98 & $-10,68$ & $-0,27$ & 2,20 & $-6,06$ & 10,44 & $-6,86$ \\
\hline Latvia & 0,05 & 0,08 & $-0,03$ & 0,13 & $-0,12$ & 0,03 & 0,06 & $-3,48$ & 0,18 & 3,27 \\
\hline Lithuania & 0,04 & 0,08 & $-0,04$ & 0,15 & $-0,16$ & 0,05 & 0,10 & $-3,99$ & 0,20 & 3,74 \\
\hline Luxembourg & $-1,04$ & $-0,83$ & $-0,34$ & 2,23 & $-2,10$ & $-0,60$ & $-0,51$ & $-5,71$ & 1,35 & 4,27 \\
\hline Malta & $-0,01$ & 0,04 & $-0,04$ & 0,18 & $-0,20$ & $-0,03$ & 0,02 & $-4,41$ & 0,20 & 4,17 \\
\hline Poland & 0,26 & 0,90 & $-0,46$ & 2,12 & $-2,31$ & 0,27 & 0,99 & $-5,26$ & 2,69 & 1,85 \\
\hline Portugal & $-0,20$ & $-0,04$ & $-0,20$ & 1,08 & $-1,04$ & 0,12 & 0,28 & $-5,22$ & 0,95 & 4,11 \\
\hline Romania & $-0,04$ & 0,08 & $-0,11$ & 0,57 & $-0,58$ & 0,00 & 0,11 & $-4,76$ & 0,58 & 4,06 \\
\hline Slovakia & 0,14 & 0,31 & $-0,30$ & 1,38 & $-1,25$ & $-0,15$ & $-0,02$ & $-5,77$ & 1,69 & 3,95 \\
\hline Slovenia & 0,03 & 0,17 & $-0,12$ & 0,54 & $-0,56$ & $-0,01$ & 0,12 & $-2,05$ & 0,55 & 1,38 \\
\hline Spain & $-0,37$ & 1,52 & $-1,09$ & 5,84 & $-6,63$ & 0,09 & 1,86 & $-4,30$ & 5,58 & $-3,05$ \\
\hline Sweden & $-0,61$ & 0,05 & $-0,68$ & 3,70 & $-3,67$ & $-0,29$ & 0,28 & $-4,29$ & 3,01 & 0,72 \\
\hline $\begin{array}{l}\text { The } \\
\text { Netherlands }\end{array}$ & $-0,70$ & 7,64 & $-13,92$ & 67,12 & $-61,54$ & 1,59 & 8,59 & $-26,85$ & 74,71 & $-54,86$ \\
\hline The UK & $-0,87$ & 7,98 & $-4,81$ & 26,85 & $-30,89$ & $-0,70$ & 8,17 & $-8,49$ & 26,15 & $-26,53$ \\
\hline
\end{tabular}

Source: own calculation based on Eurostat data

The primary effect of interest is the competitiveness effect (column 'CE'), In the first subperiod (2012-2014) the competitiveness effect was an essential factor that generated the export growth in the high-tech goods. This competitiveness effect played a crucial role in generating export growth in high technology manufactured products in Germany and France (respectively 17,74 and 14,01). Also, in the Netherlands and the UK, competitiveness played a vital role in shaping the export growth in high-tech manufactured goods, reaching respectively 7,64 and 7,98). The competitiveness effect stimulated high-tech 
goods export in 24 EU countries, and for four countries (Hungary, Finland, Luxembourg and Portugal) it caused a decrease in high-tech export.

Four countries with competitiveness-driven high-tech goods exports remained the competitiveness leaders in the next subperiod (2015-2017). In Germany, the Netherlands and the UK, the competitiveness effect was even stronger than in the previous period (15,56; 8,59 and 8,17 respectively). In France, the competitiveness effect was weaker than in the previous period. Despite this, the competitiveness factor was still the primary reason for the growth in French high-tech export. It is also worth mentioning that the competitiveness effect became one of the key drivers of high-tech export growth in Ireland.

The obtained results were slightly different from those arising from the study by other authors. Gilbert and Muchova (2018) examined the competitiveness of the CEE countries using the same CMS method. Their study showed that the most significant increases in competitiveness were observed in Poland, Slovakia and the Czech Republic, while a substantial decline in competitiveness was reported in the EU-15. These changes in the results were probably caused by the different scope of those two studies. This proves that the competitiveness of the whole economy should not be translated directly into the competitiveness of the high-tech trade.

On the other hand, these results are generally in line with our previous studies focused on high-tech competitiveness (Braja \& Gemzik-Salwach, 2019). The obtained results of Balassa RCA index showed the competitiveness of the high-tech sector in many countries, especially in Germany, the Netherlands, France and Denmark.

Another interesting conclusion can be found in the analysis of the product effect, which estimates the influence of the product specialisation of a country's exports. In the first subperiod, the product effect was negative for all the examined countries. However, the strongest negative impact was indicated in Germany and the Netherlands.

In the following period (2015-2017) the negative impact of the product effect became even worse. The product effect negatively affected high tech export growth in Germany and the Netherlands. This might suggest that the specialisation of production should be stronger. However, further examination is required to prove this hypothesis.

The market distribution effect examines if the export is directed to the prospective and growing markets. In both subperiods, the impact of this factor was positive in all the analyzed countries. It meant that the European high-tech companies exported to the growing and developing markets. This result also lets us assume that the European export of high-tech products will grow in the upcoming years.

\section{CONCLUSION AND FINAL REMARKS}

In this paper we have examined the export performance in the high-tech manufactured goods of all the EU economies over the period 2008-2017.

In the analysed period, share of high-tech trade in the EU was growing at a CAGR at $0,9 \%$ We find that in seven of the EU economies the share of the high-tech export in the total export decreased in the analysed period. In twenty seven countries the share of high-tech in the overall exports was growing, while in four CEE countries (Poland, Slovakia, Latvia and Romania) the CAGR was at least 7\% or higher.

From the perspective of the innovative and high-tech entrepreneurs, export is not a matter of choice but a necessity. The development of groundbreaking technologies or innovative products is usually timeconsuming and cost-generating. On the other hand, domestic demand for high technology products is limited and companies can secure higher rates of return by offering their products on foreign markets.

The high technology sector in the European Union is characterized by a large geographical dispersion and the sources of the competitive advantages in the high-tech sectors differ across the EU. 
In Germany, France, the United Kingdom, Ireland and the Netherlands, export growth was mostly caused by so called 'competitiveness effect', regardless of the industry. In these countries, many international companies located their $\mathrm{R} \& \mathrm{D}$ centres and decided to export their innovations to the company subsidiaries. Hence, we assume that the key competitive advantages of high-tech sectors in those countries lie in the knowledge transfer, know-how, innovation adoption, R\&D expenditures and skilled labour force. Maintain the competitive advantages, these countries should focus on the stimulation of the $R \& D$ activity, especially $R \& D$ activity aimed at the development of technologies of the future.

The estimates for the PE effect, were negative for all the EU member states. It allows for a conclusion that none of the EU countries benefits from the trade specialisation and/or in some cases the demand for the offered goods is not growing. This could be a warning signal for some countries, as in the upcoming years the demand for some offered goods may shrink and lead to losing the foreign markets.

As the estimations of geographical effect were positive for all the analysed member states, we therefore may conclude that the EU countries benefit from the geographic location.

The residual effect (RE) considers all the remaining aspects that were not incorporated into the model.

In individual European Union countries there are large disproportions regarding the degree of development of the high technology sector and its share in exports. The development of the high technology sector is a key factor determining the innovation and competitiveness of the economy and influences economic growth and development. However, for this to be properly targeted, an active state policy is needed. It should be focused on supporting modern technologies that have a large share in exports.

The growing competition in global commodity markets of less knowledge intensive products naturally pushes the EU (and the particular EU member states) for a shift to the knowledge-intensive industries. Deloitte experts predict that further development will be stimulated by the following technologies of the future: artificial intelligence, private $5 \mathrm{G}$ network, specialist service and home robotics. Hence, any public and private support for the development of these technologies will be crucial for further growth of electro sector within the EU. We are convinced that those who will acquire the best understanding of these technologies, will also gather the competitive advantages and will be able to win the future economic rivalry on the European and global level. Europe and European entrepreneurs must participate in this run, no matter which high-tech sector they operate in.

The scope of this study was limited. Therefore, the authors want to continue the analysis of the competitiveness of the high-tech exports in the EU. Further studies should therefore be focused on the examination of the main factors of the competitiveness in relatively small economies of the particular EU countries. We are mainly interested in assessing factors that affect the results of countries' high-tech exports.

\section{REFERENCES}

Ahmadi-Esfahani, F. Z. (2006). Constant market shares analysis: uses, limitations and prospects. Australian Journal of Agricultural and Resource Economics, 50(4), 510-526. doi:10.1111/j.1467-8489.2006.00364.x.

Aiginger, K. (1998). A framework for evaluating the dynamic competitiveness of countries. Structural Change and Economic Dynamics, 9(2), 159-188. doi:10.1016/s0954-349x(97)00026-x.

Bilan, Y., Nitsenko, V., Ushkarenko, I., Chmut, A., \& Sharapa, O. (2017). Outsourcing in international economic relations. Montenegrin journal of economics, 13(3), 175-185.

Bonano, G. (2014, November). A note: constant market share analysis. Munich Personal RePEc Archive Paper, 59997. Retrieved March 9, 2020, from https://mpra.ub.uni-muenchen.de/59997. 
Bowen, H. P. \& Pelzman, J. (1984). US export competitiveness: 1962-77. Applied Economics, 461-473. doi:10.1080/00036848400000051.

Braja, M. \& Gemzik-Salwach, A. (2019). Competitiveness of high-tech sectors in the European Union: A comparative study. Journal of International Studies, 12(2), 213-227. doi:10.14254/2071-8330.2019/12-2/13.

Buturac, G., Mikulić, D.\& Palić, P. (2019). Sources of export growth and development of manufacturing industry: empirical evidence from Croatia. Economic Research - Ekonomska Istraživanja, 32(1), 101-127. doi:10.1080/1331677X.2018.1550003.

Cortright, J. \& Meyer, H. (2001, January). High tech specialization: A comparison of high technology centers. The Brookings Institution. Retrieved March 9, 2020, from https://www.brookings.edu/research/high-techspecialization-a-comparison-of-high-technology-centers.

Crespo-Guaresma, J. \& Worz, J. (2003). On export composition and growth. Review of World Economics, 141(1), 33-49. doi: 10.1007/s10290-005-0014-z.

Deloitte (2020). Raport Global Prognozy TMT 2020. Retrieved March 9, 2020, from https://www2.deloitte.com/pl/pl/pages/technology/articles/raport-global-marketing-trends-2020-jakchronic-autentycznosc-w-erze-technologii-cyfrowych.html.

Domańska, A. \& Zajkowski, R. (2018). Influence of state participation on business conditions and entrepreneurship in the EU countries of the former Eastern bloc. Financial Internet Quarterly 'e-Finanse', 14(2), 9-17. doi:10.2478/fiqf-2018-0008.

Dyadkova, M. \& Momchilow, G. (2014). Constant market shares analysis beyond the intensive margin of external trade. Discussion Papers, 94, Bulgarian National Bank.

Fagerberg, J. \& Sollie, G. (1987). The method of constant market share analysis reconsidered. Applied Economics, 19(12), 1571-1583. doi:10.1080/00036848700000084.

Falkowski, K. (2018). Competitiveness of the Baltic States in international high-technology goods trade. Comparative Economic Research, 21(1), 26-43. doi:10.2478/cer-2018-0002.

Fogarasi, J. (2008). Hungarian and Romanian agri-food trade in the European Union. Management, 3(1), 3-13.

Galindo-Rueda, F. \& Verger, F. (2016). OECD taxonomy of economic activities based on R\&D intensity, OECD Science, Technology and Industry Working Papers, 4, OECD Publishing, Paris. .

Gilbert, J. \& Muchova, E. (2018). Export competitiveness of Central and Eastern Europe since the enlargement of the EU, International Review of Economics and Finance 55 (2018) 78-85. doi:10.1016/j.iref.2018.01.008.

Gökmen, Y., \& Turen, U. (2010). The determinants of high technology exports volume: A panel data analysis of EU15 countries, International Journal of Management, Economics and Social Sciences, 2(3), 217-232.

Grossman, G. E. \& Helpman, E. (2015). Globalization and growth. American Economic Review: Papers \& Proceedings, 105(5), 100-104. doi:10.1257/aer.p20151068.

Hatzichronoglou, T. (1996). Revision of the high technology sector and product classification. OECD Science, Technology and Industry Working Papers, 2, OECD Publishing, Paris.

Houston, D. B. (1967). The shift and share analysis of regional growth. A Critique' Southern Economic Journal, 33(4), 577-581.

Janoskova, K. \& Kral, P. (2019). An in-depth analysis of the summary innovation index in the V4 countries. Journal of Competitiveness, 11(2), 68-83.

Kiselakova, D., Sofrankova, B., Cabinova, V., Onuferova, E., \& Soltesova, J. (2018). The impact of R\&D expenditure on the development of global competitiveness within the CEE EU countries. Journal of Competitiveness, 10(3), 34-50. doi:10.7441/joc.2018.03.03

Kovačič, A. (2005, March). Competitiveness as a source of development, Working Paper, 28. Institute for Economic Research, Ljubljana. Retrieved March 9, 2020, from http://www.ier.si/files/Working\%20paper-28.pdf.

Leamer, E. F. \& Stern, R. M. (1970). Quantitative international economics. Chicago: Aldine Transaction Editor.

Lu, Y., \& Yu, F. (2010). The evaluation of the innovation capability of China's high-tech industries. International Business Research, 3(2), 87-91. doi:10.5539/ibr.v3n2p87.

Maciejewski, M. \& Wach, K. (2019). What determines export structure in the EU countries? The use of gravity model in international trade based on the panel data for the years 1995-2015. Journal of International Studies, 12(1), 151-167. doi:10.14254/2071-8330.2019/12-1/10

McKinsey (2019). China and the world. Inside the dynamics of a changing relationship, June.

Merkies, A. H. Q. M., \& van der Meer, T. (1988). A theoretical foundation for Constant Market Share analysis. Empirical Economics, 13, 65-80. 
Milana, C. (1988). Constant-market-shares analysis and index number theory. European Journal of Political Economy, 4(4), 453-478.

Montobbio, F., \& Rampa, F. (2005). The impact of technology and structural change on export performance in nine developing countries. World Development, 33(4), 527-547. doi:10.1016/j.worlddev.2005.01.001.

Nuddin, A. J. A., Azhar, A. K. M., Gan, V. B. Y. \& Khalifah, N. A. (2018). A new constant market share competitiveness index. Malaysian Journal of Mathematical Sciences, 12(1), 1-23.

Olczyk, M., \& Kordalska, A. (2018). Determinants of trade balance in Polish and Czech manufacturing sectors. Equilibrium. Quarterly Journal of Economics and Economic Policy, 13(3), 445-466. doi:10.24136/eq.2018.022.

Oldersma, H., \& Van Bergeijk, P. A. G. (1993). Not so constant! The constant-market-shares analysis and the exchange rate, De Economist, 141, 380-401. https://doi.org/10.1007/BF01717406.

Ozawa, T. (1992). Foreign direct investment and economic development. Transnational Corporations, I(1), 27-54.

Pasierbiak, P. (2013). The Technological Leadership of the Japanese Economy?, Acta Asiatica Varsoviensia, 26.

Porter, M. E., Sachs J. \& McArthur J., (2001). Competitiveness and stages of economic development. Global Competitiveness Report. World Economic Forum. Retrieved March 9, 2020, from http://sdnbd.org/sdi/issues/economy/ExecSumm-competitiveness-ranking-2001.pdf.

Richardson, J. (1971). Some sensitivity tests for a "Constant-Market-Shares" analysis of export growth. The Review of Economics and Statistics, 53(3), 300-304. doi:10.2307/1937978

Simonen, J., Svento, R., \& Juttinen, A. (2013). Specialization and diversity as drivers of economic growth: Evidence from high-tech industries. Papers in Regional Science, 94(2), 229-247.

Skórska, A. (2016). High-tech industry and knowledge intensive services as carriers of knowledge-based economy in Poland and in other European Union Member States, Folia Pomer. Univ. Technol. Stetin., Oeconomica, 85, 137146, doi:10.21005/oe.2016.85.4.14.

Skriner, E. (2009, April). Competitiveness and specialisation of the Austrian export sector. A constant-market-shares analysis. FIW Working Paper, 32, Retrieved March 9, 2020, from https://www.fiw.ac.at/fileadmin/Documents/Publikationen/Working_Paper/N_032-skrinerII.pdf.

Srholec M., 2007. High-Tech exports from developing countries: a symptom of technology spurts or statistical illusion?. Review of World Economics 143(2), 227-255.

Tyszynski, H. (1951). World trade in manufactured commodities. The Manchester School, 19(3), $272-304$. doi:10.1111/j.1467-9957.1951.tb00012.x

Wang, Z. X., Zheng, H. H., Pei, L. L., \& Jin, T. (2017). Decomposition of the factors influencing export fluctuation in China's new energy industry based on a constant market share model. Energy Policy, 109(C), 22-35.

Widodo, T. (2010). Market dynamics in the EU, NAFTA, North East Asia and ASEAN: The method of constant market shares (CMS) analysis. Journal of Economic Integration, 25(3), 480-500. Retrieved March 9, 2020, from

World Bank. (2020). High technology exports (in \% of manufactured goods), https://data.worldbank.org/indicator/TX.VAL.TECH.MF.ZS, access: 21.03.2020.

Yildirim, M., Özsoy, F.N., Özpolat, A., \& Çayirağasi, F. (2017). Comparative analysis of competition power in high technology and low technology intensive manufactures. International Journal of Innovation and Economic Development, 3(4), 41-52. 